Potravinarstvo Slovak Journal of Food Sciences vol. 13, 2019, no. 1, p. 258-261

https://doi.org/10.5219/1067

Received: 11 February 2019. Accepted: 11 March 2019.

Available online: 27 April 2019 at www.potravinarstvo.com

(C) 2019 Potravinarstvo Slovak Journal of Food Sciences, License: CC BY 3.0

ISSN 1337-0960 (online)

\title{
OCCURENCE AND ANTIMICROBIAL RESISTANCE OF COMMON UDDER PATHOGENS ISOLATED FROM SHEEP MILK IN SLOVAKIA
}

\author{
Ivan Holko, Vladimír Tančin, Kristína Tvarožková, Peter Supuka, Anna Supuková, \\ Lucia Mačuhová
}

\begin{abstract}
The aim of this work is to identify the spectrum, frequency and antimicrobial resistance of bacterial pathogens occurring in sheep dairy herds in Slovakia. Of a total of 310 samples of sheep's milk coming from three breeds during two seasons (2017 and 2018), at least one potential pathogen was isolated from 102 samples (32.9\%). A total of 131 microbial isolates were isolated. The most represented species were coagulase negative staphylococci CoNS (75.6\%), followed by Streptococcus agalactiae (10.7\%), Staphylococcus aureus (6.9\%), Streptococcus dysgalactiae (4.6\%), Escherichia coli (1.5\%), Enterococcus faecium (1.5\%), and others (Streptococcus uberis, Streptococcus parauberis, Candida sp., Klebsiella sp., moulds) below 1\%. A total of 99 isolates of CoNS were tested for antimicrobial resistance. Of these, $63.6 \%$ were resistant to at least one antibiotic. A total of $24.2 \%$ of the tested isolates were resistant to 3 groups of antimicrobials simultaneously (multi-drug resistance). The highest resistance was observed to lincomycin (57.6\%) and neomycin (36.4\%), the lowest to sulfamethoxazolum+trimethoprim (0\%) and enrofloxacin (3.0\%). Based on the results of this work, it is possible to assume a similar spectrum of pathogens and their antimicrobial resistance described in the literature also within the Slovak sheep farms focused on milk production.
\end{abstract}

Keywords: sheep; milk; mastitis; pathogen; antibiotic

\section{INTRODUCTION}

Public health problems associated with consumption of unpasteurized cow's milk and raw-milk products have been well documented (De Buyser et al., 2001; Harrington et al., 2002). There is no evidence that the risk from unpasteurized ewe's milk is any lower (Allerberger et al., 2001; McIntyre et al., 2002). Pathogenic microorganisms can gain access to milk either by faecal contamination or by direct excretion from the udder into the milk.

The importance of subclinical mastitis as a limiting factor in sheep's milk production is well-known. In addition to decreased milk yield, decreased viability of lambs, subclinical mastitis also greatly reduces the hygienic quality of milk as well as its technological properties.

Current knowledge of mastitis in small ruminants has been reviewed by some authors (Bergonier et al., 1999; Bergonier and Berthelot, 2003; Lafi et al., 1998; Contreras et al., 2007). The causative organisms of mastitis are categorized as major or minor pathogens (Harmon, 1994). The most common major pathogens include Staphylococcus aureus, Streptococcus agalactiae, coliforms and enterococci, while other pathogens such as Streptococcus spp., Pseudomonas aeruginosa, Mannheimia hemolytica, Corynebacteria, Coagulase negative staphylococci and fungi, are considered to be minor pathogens which can produce intramammary infection in small ruminants, but occurrence rates are lower (Contreras et al., 2007).

Differences in climatic conditions, production patterns, breeding management and breeding practices influence the different epidemiology and clinical manifestation of sheep milk. The aim of this work is to identify the spectrum, frequency and antimicrobial resistance of bacterial pathogens occurring in sheep dairy herds in Slovakia.

\section{Scientific hypothesis}

Staphylococci and streptococci are the most common cause of mastitis in milk sheep and their occurrence in milk is frequent. Antibiotics are not used in sheep as often as in dairy cows, but antimicrobial resistance can occur as the environmental impact to farm animals.

\section{MATERIAL AND METHODOLOGY}

\section{Sampling and culture}

During two seasons, samples of milk from 3 sheep farms were withdrawn repeatedly in the number 160 (season 2017) and 150 (season 2018). The animals for collection were selected by random selection. The breeding 
organization was the following: farm 1 - Slovak Tsigaya, farm 2 - Lacaune, farm 3 - Slovak Walachian/Lacaune. Milk samples of volume $10 \mathrm{~mL}$ were collected into sterile tubes from both halves after disinfection and two streaks. After sampling, the samples were cooled to $5-10{ }^{\circ} \mathrm{C}$, then frozen and transported to the laboratory. Bacteriological examination was performed within 5 days after collection. Milk samples (10 $\mu \mathrm{L}$ inoculum) were cultured on a selective diagnostic PM test (Lab-Media-Servis, CZ) at $37{ }^{\circ} \mathrm{C}$ for 24 hours. Isolated strains of pathogens were subsequently verified by typing with BBL Crystal ${ }^{\circledR}$ (Becton, Dickinson \& Co., New Jersey, USA). A milk sample was classified as positive if at least one colony-forming unit (CFU) of S. aureus or Streptococcus (Str.) agalactiae was isolated. For other agents, the presence of at least three CFUs was needed for positive classification. Samples were classified as contaminated if three or more bacterial types were isolated from one milk sample and growth of a major udder pathogen was not identified. If growth of a major udder pathogen was found in combination with contaminating species, the sample would be diagnosed as positive for growth of the major udder pathogen.

\section{Susceptibility testing}

In vitro susceptibility of the isolates against antimicrobial agents was determined by the standard disk diffusion procedure (CLSI 2008; 2013).

Coagulase-negative staphylococci $(n=99)$ were tested for susceptibility to 6 antimicrobial agents from the following groups: penicillin (amoxicillin+clavulanic acid 2:1 AMC), tetracyclines (tetracycline TET), aminoglycosides (neomycin NEO), lincosamides (lincomycin LCM), sulphonamides (sulfametoxazolum-trimethoprim SXT), and quinolones (enfofloxacin EFX). The isolates were tested by disc diffusion method according to the CLSI manual (CLSI 2008; 2013) using the following antimicrobial discs (Oxoid, Basingstoke, England): AMC $(30 \mu \mathrm{g})$, NEO $(30 \mu \mathrm{g})$, TET $(30 \mu \mathrm{g})$, LCM $(2 \mu \mathrm{g})$, SXT $(25 \mu \mathrm{g})$, EFX $(5 \mu \mathrm{g})$. The diameters of the inhibition zones were evaluated (susceptible, intermediate, resistant) according to CLSI breakpoints. Appropriate quality control tests were performed using reference strains of $E$. coli ATCC 25922, Staphylococcus aureus ATCC 29213 and Enterococcus faecalis ATCC 29212.

\section{Statistic analysis}

Simple descriptive statistics was used. The results of cultivation were processed into a percentage of individual microbial species. The results of antimicrobial resistance were also expressed as the percentage of resistant isolates in each type of antimicrobial.

\section{RESULTS AND DISCUSSION}

Of a total of 310 samples of sheep's milk coming from three farms, at least one potential pathogen was isolated from 102 samples $(32.9 \%)$. The results are shown in the Table 1. The most represented pathogens were coagulase negative staphylococci CoNS, namely Staphylococcus chromogenes, Staphylococcus epidermidis, Staphylococcus xylosus $(75.6 \%)$, followed by Streptococcus agalactiae (10.7\%), Staphylococcus aureus (6.9\%), Streptococcus dysgalactiae (4.6\%), Escherichia coli (1.5\%), Enterococcus faecium (1.5\%) and others (Streptococcus uberis, Streptococcus parauberis, Candida sp., Klebsiella sp.). The cause of the sheep's mastitis may be a number of microorganisms, according to the literature, they are mainly representatives of the genus Staphylococcus (Bergonier and Berthelot, 2003; Zigo et al., 2011). The results of this work also confirm this bacterial genus as dominant in the farming conditions included in our observation, in both consecutive seasons.

Several authors state that CoNS are most frequent pathogens responsible for subclinical mastitis of dairy sheep (Fthenakis, 1994; Burriel, 1997; Lafi et al., 1998; Pengov, 2001; Ariznabarreta, Gonzalo and San Primitivo, 2002; Gonzalo et al., 2002) and Staphylococcus aureus is more frequent in meat sheep (Jones, 1991; Watson et al., 1990; Hariharan et al., 2004; Mork et al., 2007). The farms included in this work are focused on the production of sheep's milk and CoNS represent a significant prevalence of all isolated pathogens. Staphylococcus aureus represented less than $7 \%$ of isolates.

Streptococci are probably the second most common cause of ovine mastitis (Bergonier et al., 1999). The most commonly isolated species are Streptococcus agalactiae, Streptococcus uberis and Streptococcus dysgalactiae (Las Heras et al., 2002). In this work streptococci were mainly represented by Streptococcus agalactiae, but only in the first of the monitored seasons. In the second year of followup, the occurrence of streptococci in the samples taken decreased significantly. This difference could have been caused by certain breeding measures in the context of milk management and overall hygiene in the farm. The presence of other pathogens in the isolates obtained in this work was negligible.

Antibiotic resistance pattern for staphylococci isolated from subclinical mastitis refers mainly to cattle, and little is known about dairy sheep.

A total of 99 isolates of CoNS were tested for antimicrobial resistance. Of these, $63.6 \%$ were resistant to at least one antibiotic. A total of $24.2 \%$ of the tested isolates were resistant to 3 antimicrobials simultaneously. The highest resistance was observed to lincomycin (57.6\%) and neomycin (36.4\%), the lowest to sulfamethoxazolum+trimethoprim $(0 \%)$ and enrofloxacin (3.0\%). The results are shown in Table 2.

The high multidrug resistance rates observed in CoNS are in accordance with previous reports (Kumar, Yadav and Singh, 2009; Sawant, Gillespie and Oliver, 2009; Vasil' et al., 2018) and support the hypothesis that CoNS might play an important role as a source of genes resistant to $S$. aureus (Taponen and Pyörälä, 2009). Considering such an assumption, studies about host specificity in Staphylococcus aureus and other pathogenic agents could provide useful information about the epidemiological importance of CoNS as reservoirs of genes resistant to pathogenic strains for humans. However, because CoNS are the major mastitis causing agents in small ruminants, the high frequency of resistant genes in such species reported here is worth noting. 
Table 1 The numbers of microbial pathogens isolated from three sheep farms during two seasons in 2017 and 2018.

\begin{tabular}{|c|c|c|c|c|c|c|c|}
\hline \multirow{3}{*}{ Pathogen } & \multicolumn{6}{|c|}{ No. of isolates in the season } & \multirow{3}{*}{ Total } \\
\hline & \multicolumn{3}{|c|}{2017} & \multicolumn{3}{|c|}{2018} & \\
\hline & Farm 1 & Farm 2 & Farm 3 & Farm 1 & Farm 2 & Farm 3 & \\
\hline Staphylococcus chromogenes & 13 & 6 & 7 & 4 & 2 & 8 & 40 \\
\hline Staphylococcus epidermidis & 3 & 4 & 3 & 3 & 4 & 3 & 20 \\
\hline Staphylococcus xylosus & 8 & 14 & 5 & 4 & 3 & 5 & 39 \\
\hline Staphylococcus aureus & 0 & 4 & 2 & 2 & 1 & 0 & 9 \\
\hline Streptococcus agalactiae & 9 & 1 & 4 & 0 & 0 & 0 & 14 \\
\hline Streptococcus dysgalactiae & 1 & 1 & 2 & 2 & 0 & 0 & 6 \\
\hline Streptococcus uberis & 1 & 0 & 0 & 0 & 0 & 0 & 1 \\
\hline Streptococcus parauberis & 1 & 0 & 0 & 0 & 0 & 0 & 1 \\
\hline Escherichia coli & 0 & 2 & 0 & 0 & 0 & 0 & 2 \\
\hline Klebsiella sp. & 0 & 0 & 0 & 0 & 1 & 0 & 1 \\
\hline Enterococcus faecium & 1 & 1 & 0 & 0 & 0 & 0 & 2 \\
\hline Candida sp. & 0 & & & 0 & 0 & 0 & 1 \\
\hline Micromycetes & 0 & 0 & 1 & 0 & 0 & 0 & 1 \\
\hline
\end{tabular}

Table 2 The results of antimicrobial resistance testing of coagulase negative staphylococci.

\begin{tabular}{ccccc}
\hline & Zone diameters & \multicolumn{3}{c}{$\begin{array}{c}\text { No. of isolates/percentage } \\
(\mathbf{n = 9 9 )}\end{array}$} \\
\cline { 3 - 5 } Antimicrobials & $\mathbf{S}-\mathbf{I}-\mathbf{R})$ & Sensitive & Intermediate & Resistant \\
\hline Amoxicillin+clavul. & $\geq 30,29-28, \leq 27$ & $81 / 81.8$ & $3 / 3.0$ & $15 / 15.2$ \\
Tetracycline & $\geq 19,18-15, \leq 14$ & $72 / 72.7$ & 0 & $27 / 27.3$ \\
Lincomycin & $\geq 20,19-17, \leq 16$ & $33 / 33.3$ & $9 / 9.1$ & $57 / 57.6$ \\
Enrofloxacin & $\geq 25,24-21, \leq 20$ & $81 / 81.8$ & $15 / 15.2$ & $3 / 3.0$ \\
Sulphametoxazolum+trimet. & $\geq 19,18-16, \leq 15$ & $96 / 97.0$ & $3 / 3.0$ & $0 / 0$ \\
Neomycin & $\geq 23,22-20, \leq 19$ & $36 / 36.4$ & $27 / 27.3$ & $36 / 36.4$ \\
\hline
\end{tabular}

The drugs showing the lowest resistance rates were enrofloxacin and sulphonamides, which are in accordance with other studies on mastitis in several ruminant species (Kumar et al., 2009). Virdis et al. (2010) reported high sensitivity to quinolones, but not to aminoglycoside in subclinical mastitis-causing staphylococci.

From the point of view of epizootology, CoNS are frequently found to be a pathogenic especially in the case of subclinical mastitis. They do not represent a major specific pathogen but can potentially cause infections that tend to have a mild clinical manifestation but cause losses in the milk production, in quantity and quality of milk.

\section{CONCLUSION}

Based on the results of this work, it is possible to assume a similar spectrum of pathogens and their antimicrobial resistance described in the literature also within the Slovak sheep farms focused on milk production. Coagulase negative staphylococci, as the most common pathogen, poses a risk in the form of a subclinical course of inflammatory changes in the mammary gland that often escape the attention of breeders, but can have a significant impact on the quality of milk production.

\section{REFERENCES}

Allerberger, F., Wagner, M., Schweiger, P., Rammer, H. P., Resch, A., Dierich, M. P., Friedrich, A.W., Karch, H. 2001. Escherichia coli $\mathrm{O} 157$ infections and unpasteurised milk. European Surveillance, vol. 6, no. 10, p. 147-151. https://doi.org/10.2807/esm.06.10.00379-en
Ariznabarreta, A., Gonzalo, C., San Primitivo, F. 2002. Microbiological quality and somatic cell count of ewe milk with special reference to staphylococci. J. Dairy. Sci., vol. 85, no. 6, p. 1370-1375. https://doi.org/10.3168/jds.S0022$\underline{0302(02) 74203-3}$

Bergonier, D., Berthelot, X. 2003. New advances in epizootiology and control of ewe mastitis. Livest. Prod. Sci., vol. 79, no. 1, p. 1-16. https://doi.org/10.1016/S0301$\underline{6226(02) 00145-8}$

Bergonier, D., Berthelot, X., Romeo, M., Contreras, A., Coni, V., De Santis, E., Roselu, S., Barillet, F., Lagriffoul, G., Marco, J. 1999. Frequency of various germs responsible for clinical and subclinical mastitis in small dairy ruminants (Fréquence des différents germes responsables de mammites cliniques et subcliniques chez les petits ruminants laitiers). In: Barillet, F., Zervas, N. P. Milking and milk production of dairy sheep and goats. Wageningen, The Netherlands : Wageningen Press, p. 130-136. ISBN 9789074134644. (In French)

Burriel, A. R. 1997. Dynamics of intramammary infection in the sheep caused by coagulase-negative staphylococci and its influence on udder tissue and milk composition. Vet. Rec., vol. 140, no. 16, p. 419-423. https://doi.org/10.1136/vr.140.16.419

CLSI (Clinical and Laboratory Standards Institute). 2008 Development of In Vitro Susceptibility Testing Criteria and Quality Control Parameters for Veterinary Antimicrobial Agents. Approved Guideline VET02-A3. $3^{\text {rd }}$ ed. Wayne, Pennsylvania : Clinical and Laboratory Standards Institute. 43 p. ISBN 1-56238-660-3.

CLSI. 2013 Performance Standards for Antimicrobial Disk and Dilution Susceptibility Tests for Bacteria Isolated From Animals. Approved Standard VET01-A4. $4^{\text {th }}$ ed. Wayne, Pennsylvania : Clinical and Laboratory Standards Institute, 156 p. ISBN 978-1-68440-008-9. 
Contreras, A., Sierra, D., Sanchez, A., Corrales, J. C., Marco, J. C. 2007. Mastitis in small ruminants. Small Rumin. Res., vol. 68, no. 1-2, $145-153$. https://doi.org/10.1016/j.smallrumres.2006.09.011

De Buyser, M. L., Dufour, B., Maire, M., Lafarge, V. 2001. Implication of milk and milk products in food-borne diseases in France and in different industrialised countries. Int. J. Food Microbiol., vol. 67, no. 1-2, p. 1-17. https://doi.org/10.1016/S0168-1605(01)00443-3

Fthenakis, G. C. 1994. Prevalence and aetiology of subclinical mastitis ewes of Southern Greece. Small Rumin. Res., vol. 13, no. 3, p. 293-300. https://doi.org/10.1016/09214488(94)90078-7

Gonzalo, C., Ariznabarreta, A., Carriedo, J. A., San Primitivo, F. 2002. Mammary pathogens and their relationship to somatic cell count and milk yield losses in dairy ewes. $J$. Dairy Sci., vol. 85, no. 6, p. 1460-1467. https://doi.org/10.3168/jds.S0022-0302(02)74214-8

Hariharan, H., Donachie, W., Macaldowie, C., Keefe, G. 2004. Bacteriology and somatic cell counts in milk samples from ewes on a Scottish farm. Canadian J. Vet. Res., vol. 68, no. 3, p. 188-192.

Harmon, R. J. 1994. Physiology of mastitis and factors affecting somatic cell count. J. Dairy Sci., vol. 7, no. 7, p. 21032112. https://doi.org/10.3168/jds.S0022-0302(94)77153-8

Harrington, P., Archer, J., Davis, J. P., Croft, D. R., Varma, J. K., EIC officers. 2002. Outbreak of Campylobacter jejuni infections associated with drinking unpasteurized milk procured through a cow-leasing program-Wisconsin, 2001. Morb. Mortal. Wkly. Rep., vol. 51, p. 548-549.

Jones, J. E. T. 1991. Mastitis in sheep. In Owen, J. B., Axfor, R.F.E. Breeding for Disease Resistance in Farm Animals. Bangor, Tucson, AZ : CAB International, p. 412-423. ISBN 0851993257.

Kumar, R., Yadav, B. R., Singh, R. S. 2009. Genetic determinants of antibiotic resistance in Staphylococcus aureus isolates from milk of mastitic crossbred cattle. Curr. Microbiol., vol. 60, no. 5, p. 379-386. https://doi.org/10.1007/s00284-009-9553-1

Lafi, S. Q., Al-Majali, A. M., Rousan, M. D., Alawneh, J. M. 1998. Epidemiological studies of clinical and subclinical ovine mastitis in Awassi sheep in northern Jordan. Prev. Vet. Med., vol. 33, no. 1-4, p. 171-181. https://doi.org/10.1016/S01675877(97)00048-2

Las Heras, A., Vela, A. I., Fernández, E., Legaz, E., Domínguez, L., Fernández-Garayzábal, J. F. 2002. Unusual Outbreak of Clinical Mastitis in Dairy Sheep Caused by Streptococcus equi subsp. zooepidemicus. J. Clin. Microbiol., vol. 40, no. 3, p. 1106-1108. https://doi.org/10.1128/JCM.40.3.1106-1108.2002

McIntyre, L., Fung, J., Paccagnella, A., Isaac-Renton, J., Rockwell, F., Emerson, B., Preston, T. 2002. Escherichia coli O157 outbreak associated with the ingestion of unpasteurized goat's milk in British Columbia, 2001. Can. Commun. Dis. Rep., vol. 28, no. 1, p. 6-8.

Mork, T., Waage, S., Tollesrud, T., Kvitle, B., Sviland, S. 2007. Clinical mastitis in ewes; bacteriology, epidemiology and clinical features. Acta. Vet. Scand., vol. 49, no. 1, p. 23. https://doi.org/10.1186/1751-0147-49-23

Pengov, A. 2001. The role of coagulase-negative Staphylococcus spp. and associated somatic cell count in the ovine mammary gland. J. Dairy Sci., vol. 84, no. 3, p. 572-574. https://doi.org/10.3168/jds.S0022-0302(01)74509-2
Sawant, A. A., Gillespie, B. E., Oliver, S. P. 2009. Antimicrobial susceptibility of coagulase-negative Staphylococcus species isolated from bovine milk. Vet. Microbiol., vol. 134, no. 1-2, p. 73-81. https://doi.org/10.1016/j.vetmic.2008.09.006

Taponen, S., Pyörälä, S. 2009. Coagulase-negative staphylococci as cause of bovine mastitis - not so different from Staphylococcus aureus? Vet. Microbiol., vol. 134, no. 12, p. 29-36. https://doi.org/10.1016/j.vetmic.2008.09.011

Vasil', M., Elečko, J., Farkašová, Z., Zigo, F. 2018. Development of resistance to antibiotics in bacteria Staphylococcus spp. isolated from milk samples in the sheep breedings on east of Slovakia. Potravinarstvo Slovak Journal of Food Sciences, vol. 12, no. 1, p. 273-278. https://doi:10.5219/904

Virdis, S., Scarano, C., Cossu, F., Spanu, V., Spanu, C., Santis, E. P. L. 2010. Antibiotic resistance in Staphylococcus aureus and coagulase negative staphylococci isolated from goats with subclinical mastitis. Vet. Med. Int., vol. 2010, p. 5170-5176. https://doi.org/10.4061/2010/517060

Watson, D. L., Franklin, N. A., Davies, H. I., Kettlewell, P., Frost, A. J. 1990. Survey of intramammary infections in ewes on the New England Tableland of New South Wales. Aust. Vet. J., vol. 67, no. 1, p. 6-8. https://doi.org/10.1111/j.17510813.1990.tb07381.x

Zigo, F., Vasil', M., Kadáši, M., Elečko, J., Farkašová, Z. 2011. Bacteria Staphylococcus spp. isolated from mastitis of sheep and their enterotoxigenic properties. Potravinarstvo, vol. 5, no. 4, p. 70-72. https://doi.org/10.5219/171

\section{Acknowledgments:}

This work was supported by grant APVV-15-0072.

\section{Contact address:}

*Ivan Holko, VETSERVIS, s.r.o., Kalvária 3, 94901 Nitra, Slovakia, Tel.: +421905139876, E-mail: holko@vetservis.sk

Vladimír Tančin, Slovak University of Agriculture, Faculty of Agrobiology and Food Resources, Department of veterinary science, Tr. A. Hlinku 2, 94976 Nitra, Slovakia; NPPC-Research Institute for Animal Production Nitra, Hlohovecká 2, 95141 Lužianky Slovakia, Tel., +421376414461, E-mail: tancin@vuzv.sk

Kristína Tvarožková, Slovak University of Agriculture, Faculty of Agrobiology and Food Resources, Department of Veterinary Disciplines, Trieda A. Hlinku 2, 94976 Nitra, Slovakia, Tel: $\quad+421944385272, \quad$ E-mail: kristina.tvarozkova@gmail.com

Peter Supuka, VETSERVIS, s.r.o., Kalvária 3, 94901 Nitra, Slovakia, Tel.: +421905748041, E-mail: supuka.peter@gmail.com

Anna Supuková, VETSERVIS, s.r.o., Kalvária 3, 94901 Nitra, Slovakia, Tel.: +421915986733, E-mail: supukova@vetservis.sk

Lucia Mačuhová, NPPC-Research Institute for Animal Production Nitra, Hlohovecká 2, 95141 Lužianky, Slovakia, Tel.: +421376545171, E-mail: macuhova@vuzv.sk

Corresponding author: * 